\title{
Short Communication / Nota Científica \\ What are the species of phorophytes of Vanilla palmarum (Orchidaceae) in Brazil? An assessment of emblematic specificity with palm tree species
}

\author{
Felipe Fajardo Villela Antolin Barberena ${ }^{1,5}$, Tainan da Silva Sousa ${ }^{2,3}$, Bianca de Souza Ambrosio-Moreira ${ }^{4}$ \\ \& Nádia Roque ${ }^{2}$
}

\begin{abstract}
Vanilla palmarum is an obligately epiphytic orchid distributed widely throughout South America with emblematic specificity for species of palms. This epiphyte-phorophyte association was examined through the analysis of specimens available via the database of Centro de Referência em Informação Ambiental and from Brazilian herbaria. We recognized nine species as hosts of V. palmarum in Brazil: Acrocomia aculeata, Attalea phalerata, Attalea speciosa, Elaeis guineensis, Mauritia flexuosa, Syagrus cearensis, S. coronata, S. schizophylla, and $S$. vagans. The most important phorophytes of $V$. palmarum were found to be $A$. speciosa (Cerrado), A. phalerata (Pantanal), M. flexuosa (Amazon Forest) and S. coronata (Caatinga). Future management actions must consider the association between $V$. palmarum and its phorophyte palm species in order to ensure the protection of this ecological interaction.
\end{abstract}

Key words: botanical collections, ecological interactions, endemism, orchid, phytogeographic domains.

\begin{abstract}
Resumo
Vanilla palmarum (Orchidaceae) é uma holoepífita obrigatória, amplamente distribuída na América do Sul, e apresenta uma emblemática especificidade com palmeiras. A interação epífita-forófitos foi examinada através da análise de espécimes disponíveis na base de dados do Centro de Referência em Informação Ambiental e em herbários brasileiros. Nós reconhecemos nove espécies hospedeiras de V. palmarum no Brasil: Acrocomia aculeata, Attalea phalerata, Attalea speciosa, Elaeis guineensis, Mauritia flexuosa, Syagrus cearensis, S. coronata, S. schizophylla e S. vagans. Os principais forófitos de V.palmarum são: A. speciosa (Cerrado), A. phalerata (Pantanal), M. flexuosa (Floresta Amazônica) e $S$. coronata (Caatinga). As futuras ações de manejo devem considerar a associação entre $V$. palmarum e espécies de palmeiras, visando assegurar a proteção das interações ecológicas. Palavras-chave: coleções botânicas, interações ecológicas, endemismos, orquídea, domínios fitogeográficos.
\end{abstract}

A great diversity of epiphytes is concentrated in the Neotropics, mainly in the Andes and the Amazon and Atlantic forests (Barthlott et al. 1999; Freitas et al. 2016). A better understanding of the specificity between epiphytes and their phorophytes is essential for the conservation of both groups, however, this association remains understudied (e.g., Trapnell \& Hamrick 2006; Huda \& Wilcock 2011; Wagner et al. 2015).
Vanilla palmarum (Salzm. ex Lindl.) Lindl. is an obligately epiphytic orchid (misunderstood as an hemiepiphyte, see Pansarin et al. 2012) distributed widely throughout South America (Soto Arenas \& Cribb 2010). In Brazil, the species occurs in the Amazon Forest, Atlantic Forest, Caatinga and Cerrado phytogeographic domains (Freitas et al. 2011; BFG 2015). Vanilla palmarum is autogamous and easily distinguished from other Vanilla Mill.

\footnotetext{
${ }^{1}$ Universidade Federal Rural da Amazônia, Estrada do Pau Amarelo s/n, Vila Nova, 68650-000, Capitão Poço, PA, Brazil.

${ }^{2}$ Universidade Federal da Bahia, Inst. Biologia, R. Barão de Jeremoabo s/n, Ondina, 40170-115, Salvador, BA, Brazil.

${ }^{3}$ Centro Universitário Jorge Amado, Av. Luís Viana 6775, Paralela, 41745-130, Salvador, BA, Brazil.

${ }^{4}$ Instituto de Pesquisas Jardim Botânico do Rio de Janeiro, Escola Nacional de Botânica Tropical, R. Pacheco Leão 2040, Jardim Botânico, 22460-036, Rio de Janeiro, RJ, Brazil.

${ }^{5}$ Author for correspondence: felipe.fajardo@ufra.edu.br
} 
species by characters such as yellow flowers without a penicillate callus, lip more than $5 \mathrm{~cm}$ long, with pubescent to hirsute longitudinal lines on the distal half, and mature odorless fruits (Householder et al. 2010; Soto Arenas \& Cribb 2010).

The specificity of $V$. palmarum to palm tree phorophyte has been recognized for decades, having been first mentioned by Lindley (1840) and corroborated by Rolfe (1896) still in the 19th century. Later, Hoehne (1949) cited the growth of the species on Attalea vitrivir Zona. Since then, $V$. palmarum has been also recorded growing on Mauritia L.f., Syagrus Mart., and other Attalea Kunth. species (Soto Arenas \& Cribb 2010; BFG 2015). Householder et al. (2010) recognized $V$. palmarum to be an obligate epiphyte on Mauritia flexuosa L.f. in Madre de Díos, Peru, whereas Attalea butyracea (Mutis ex L.f.) Wess.Boer was listed as its phorophyte in Colombia (Fotosíntesis 2012). Palms highlighted as phorophytes of $V$. palmarum in Brazil include Attalea phalerata Mart. ex Spreng. (Miranda \& Guarim Neto 2012), M. flexuosa (Pansarin et al. 2012; Koch et al. 2014) and Syagrus coronata (Mart.) Becc. (Bastos \& van den Berg 2012; Vieira et al. 2014; Castro et al. 2016), but the actual number of species that host $V$. palmarum has not been investigated. In the present study, we provided a list of phorophyte species associated with $V$. palmarum and briefly discussed future implications for the maintenance of this epiphyte-phorophyte interaction. Raw data for this study was obtained from the analysis of the labels of 326 specimens of V. palmarum available on the digital database developed by Centro de Referência em Informação Ambiental (CRIA 2017). The herbaria HF, HRB, IAN, MG, $\mathrm{RB}, \mathrm{RBR}$, which are not included in this database, were also consulted for an additional 59 specimens (acronyms according to Thiers, continuously updated). Data from the labels of specimens of $V$. palmarum regarding location of occurrence (state, municipality and phytogeographic domain) and phorophytes (mainly scientific and common names) were extracted and compiled. The main common name of each phorophyte in Brazil is presented. Data on the geographical distribution of $V$. palmarum and palm trees were obtained from BFG (2015). Maps were constructed using ARCGIS software, version 10.2.

We recorded nine palm species as phorophytes of V. palmarum in Brazil: Acrocomia aculeata (Jacq.) Lodd. (macaúba), A. phalerata (acuri), Attalea speciosa Mart. ex Spreng. (babaçu), E. guineensis Jacq. (dendezeiro), M. flexuosa (buriti), Syagrus cearensis Noblick (catolé), $S$. coronata (Mart.) Glassman (licuri), S. schizophylla (aricuriroba), and Syagrus vagans (Bondar) A.D.Hawkes (ariri) (Tab. 1). Of these, six species are reported for the first time as phorophytes of $V$. palmarum, including one species of Acrocomia Mart. (Tab. 1). The geographic distribution of $V$. palmarum is extended to include the Pantanal phytogeographic domain and the states of Minas Gerais (municipalities of Salto da Divisa and Santa Maria do Salto) and Espírito Santo (municipality of Linhares) (Fig. 1). Vanilla palmarum is now known from 132 Brazilian municipalities, of which 57 are in the state of Bahia, followed by the states of Mato Grosso (12 municipalities), Sergipe (11 municipalities), and Pernambuco (nine municipalities), with less than seven municipalities in each of the other states (Fig. 1).

About $30 \%$ of specimens analyzed (119 specimens) had information about the identification of the phorophyte to the specific level (sometimes indirectly obtained through the common name), and another 13\% (49 specimens) to the generic level or other poorly detailed levels (i.e. "palmeira", "palm tree"). The remaining 217 samples did not provide any information about the phorophytes.

We found that Vanilla palmarum occurs predominantly on a single phorophyte palm species in each phytogeographic domain and in most Brazilian states. The most important phorophytes of $V$. palmarum are Attalea speciosa (Cerrado), A. phalerata (Pantanal), Mauritia flexuosa (Amazon Forest) and Syagrus coronata (Caatinga). Elaeis guineensis, S. coronata and S. schizophylla host $V$. palmarum in the Atlantic Forest, where records are scarce (Fig. 2), making it difficult to determine if there is a most important species for this domain. In the Amazon Forest, V. palmarum was recorded growing on "buriti" palm in the states of Acre, Amazonas, Amapá and Pará (five municipalities in total; Fig. 2). Acrocomia aculeata is a secondary phorophyte within this domain with only one record (state of Mato Grosso). Similarly, A. phalerata is the most important phorophyte of $V$. palmarum in the Pantanal (records in six municipalities of Mato Grosso and two of Mato Grosso do Sul), followed by A. speciosa and A. aculeata. The three palm species also occur in ecotone areas of Cerrado-Pantanal, Cerrado-Amazon Forest or Amazon Forest-Pantanal (Fig. 2). Attalea speciosa is the main phorophyte of $V$. palmarum in Cerrado, where it has been reported in states of the North (Tocantins), Northeast (Ceará, Maranhão and Piauí) and Central-West (Goiás and Mato Grosso) 
Table 1 - Phorophytes of $V$. palmarum (Salzm. ex Lindl.) Lindl. in Brazil. Phytogeographic domains: AF = Atlantic Forest; $\mathrm{AM}=$ Amazon Forest $\mathrm{CA}=$ Caatinga $\mathrm{CE}=$ Cerrado; $\mathrm{PA}=$ Pantanal. Species cited for the first time as phorophytes of $V$. palmarum are indicated by an asterisk (*), while Brazilian endemics are indicated by a hashtag (\#). Information about phytogeographic domains was extracted from BGF (2015), with new records being indicated by boldface type.

\begin{tabular}{|c|c|c|c|c|c|}
\hline \multirow[t]{2}{*}{ Species } & \multicolumn{5}{|c|}{ Phytogeographic Domain } \\
\hline & $\mathrm{AF}$ & $\mathrm{AM}$ & CA & $\mathrm{CE}$ & $\mathrm{PA}$ \\
\hline Acrocomia aculeata (Jacq.) Lodd. ex Mart. * & $\mathrm{X}$ & $\mathrm{X}$ & $\mathrm{X}$ & $\mathrm{X}$ & $\mathbf{X}$ \\
\hline Attalea phalerata Mart. ex Spreng. & & $\mathrm{X}$ & & $X$ & $\mathbf{X}$ \\
\hline Attalea speciosa Mart. ex Spreng. *\# & & $\mathrm{X}$ & & $\mathrm{X}$ & $\mathbf{X}$ \\
\hline Elaeis guineensis Jacq. * & $\mathrm{X}$ & & & & \\
\hline Mauritia flexuosa L.f. & & $\mathrm{X}$ & $\mathrm{X}$ & $X$ & \\
\hline Syagrus cearensis Noblick *\# & $\mathrm{X}$ & & $X$ & & \\
\hline Syagrus coronata (Mart.) Becc. ${ }^{\#}$ & & & $\mathrm{X}$ & $X$ & \\
\hline Syagrus schizophylla (Mart.) Glassman *\# & $\mathrm{X}$ & & & & \\
\hline Syagrus vagans (Bondar) A.D.Hawkes *\# & & & $\mathrm{X}$ & & \\
\hline
\end{tabular}

regions of the country, whereas $A$. phalerata is a secondary phorophyte with records only for Mato Grosso. Syagrus coronata was the most frequently colonized species in Caatinga. The importance of "licuri" palm for $V$. palmarum has been reported for the states of Alagoas, Bahia, Pernambuco and Sergipe (27 municipalities in total; Fig. 2). In the states of Piauí, Ceará and Maranhão, $V$. palmarum has been recorded only on $A$. speciosa, whereas E. guineensis is the only phorophyte reported for the state of Paraíba. In Bahia, $V$. palmarum was found on E. guineensis (mainly in Atlantic Forest), S. schyzophylla (exclusively in Atlantic Forest), $S$. coronata (mainly in Caatinga) and $S$. vagans (exclusively in Caatinga) (Tab. 1; Fig. 2). Specific records of $V$. palmarum on $S$. cearensis (Pernambuco) and S. vagans (Bahia) were checked. No information was found about phorophytes of $V$. palmarum in the states of Rondônia, Minas Gerais and Espírito Santo (Fig. 2).

Hoehne (1949) mentioned A. vitrivir as a phorophyte of $V$. palmarum in Mato Grosso. However, since $A$. vitrivir does not occur in this state, and it is morphologically similar to A. speciosa, we believe this was likely a misidentification (Lorenzi et al. 2010; BFG 2015). In addition, there is no information about this orchid-phorophyte relationship in any herbarium collection. For these reasons, we cannot validate $A$. vitrivir as a host of V. palmarum.

Although M. flexuosa ("buriti") occurs in the Northeast (Caatinga) and Central-West (Cerrado) regions of Brazil (BFG 2015), there are no records of orchid-"buriti" association in these regions. This may be due to smaller populations of the "buriti" palm, a lack of orchid collections in "buritizais" or commercial overexplotation of "buriti" in these domains. The last hypothesis is based on Vieira et al. (2016), who noticed extensive harvesting of parts of $M$. flexuosa in Maranhão, including the stipe, leaves, fruits and seeds. On the other hand, Vanilla palmarum was recorded on $M$. flexuosa, Acrocomia aculeata and $A$. phalerata in several municipalities (e.g., Cáceres), which cover areas of Cerrado, Pantanal and Amazon, revealing that these palm species are phorophytes in more than one domain.

The greatest number of effective phorophytes (E. guineensis, S. schizophylla, S. coronata and $S$. vagans) and records of the $V$. palmarum-palm tree association in Bahia is probably because seven of nine palm species occur in this state (BFG 2015), with $S$. coronata forming large widely-distributed populations. The unexpected records of $S$. coronata in Atlantic Forest and E. guineensis in Caatinga can be explained by their use as ornamentals plants. Otherwise, these records may be indicative of the occurrence of $S$. coronata in Caatinga-Atlantic Forests ecotone areas, where the $V$. palmarum-palm species association needs to be further investigated.

Syagrus cearensis (endemic to few states of the Northeast Region) and S. vagans (endemic to Caatinga areas in Bahia) were the least common hosts of $V$. palmarum (only one record each). The scant records can be explained by endemism and the limited collecting that has been done in the areas of occurrence. Similarly, V. palmarum was recorded 
growing on Acrocomia aculeata in only two municipalities. Petini-Benelli et al. (2009) reported the occurrence of individuals of Cyrtopodium saintlegerianum (Orchidaceae) on phorophytes of $A$. aculeata, Attalea phalerata and $M$. flexuosa in the municipality of Poconé in Mato Grosso, but a clear preference for $A$. aculeata. Thus, we assume that this palm species can be colonized by other epiphytes in the Central-West Region, which may interfere with the establishment of $V$. palmarum.

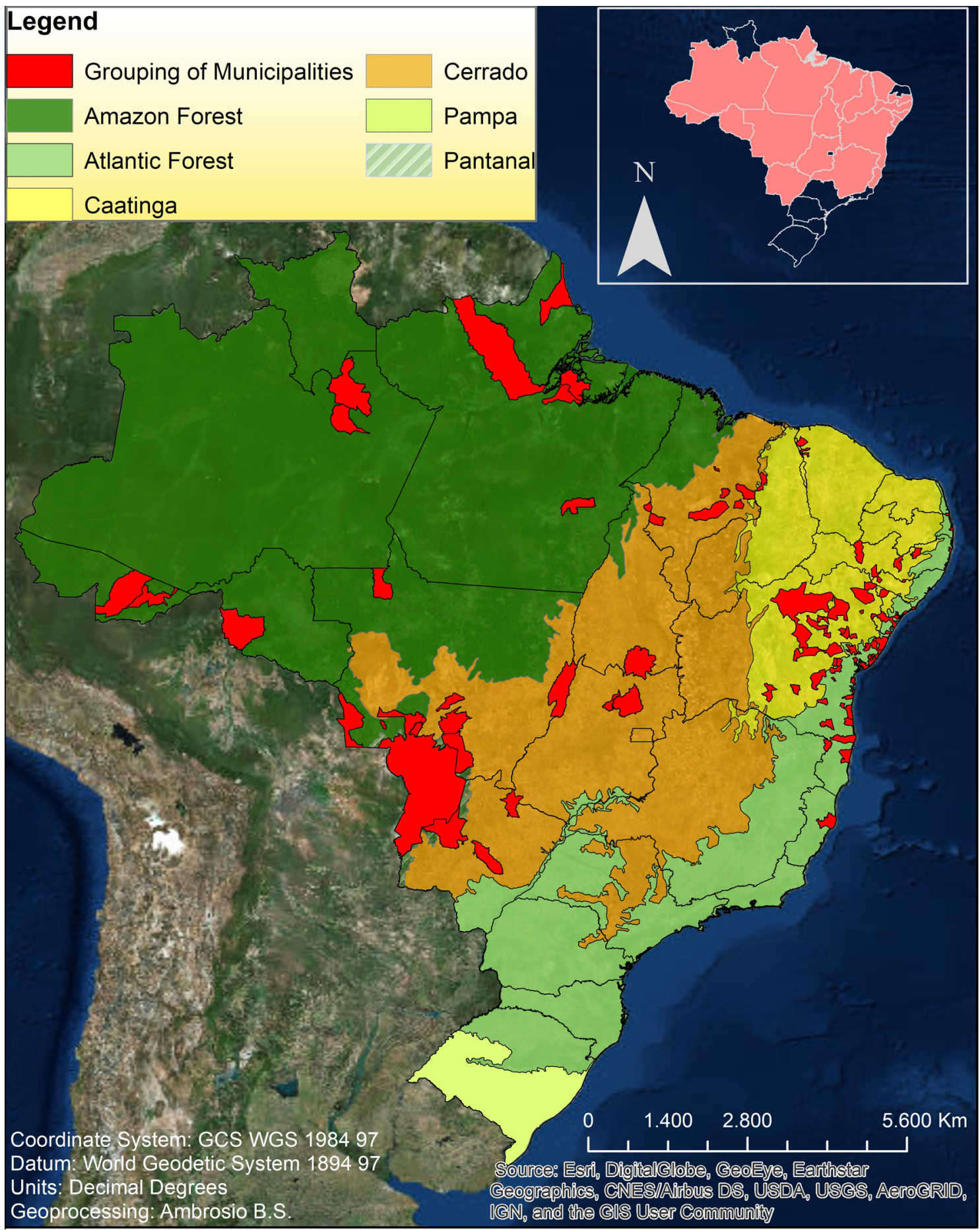

Figure 1 - Distribution of Vanilla palmarum (Salzm. ex Lindl.) Lindl. in Brazil. 
Five of the nine species of palm phorophytes of $V$. palmarum are endemic to Brazil (Tab. 1), and include regional endemism (Northeast - $S$. coronata and $S$. cearensis) or endemism related to a phytogeographic domain (Caatinga - $S$. vagans and Atlantic Forest - S. schizophylla). Unfortunately, eight of the nine palm species do not have their conservation status evaluated in Brazil, while S. schizophylla is classified as Near Threatened (Flora do Brasil 2020). Furthermore,

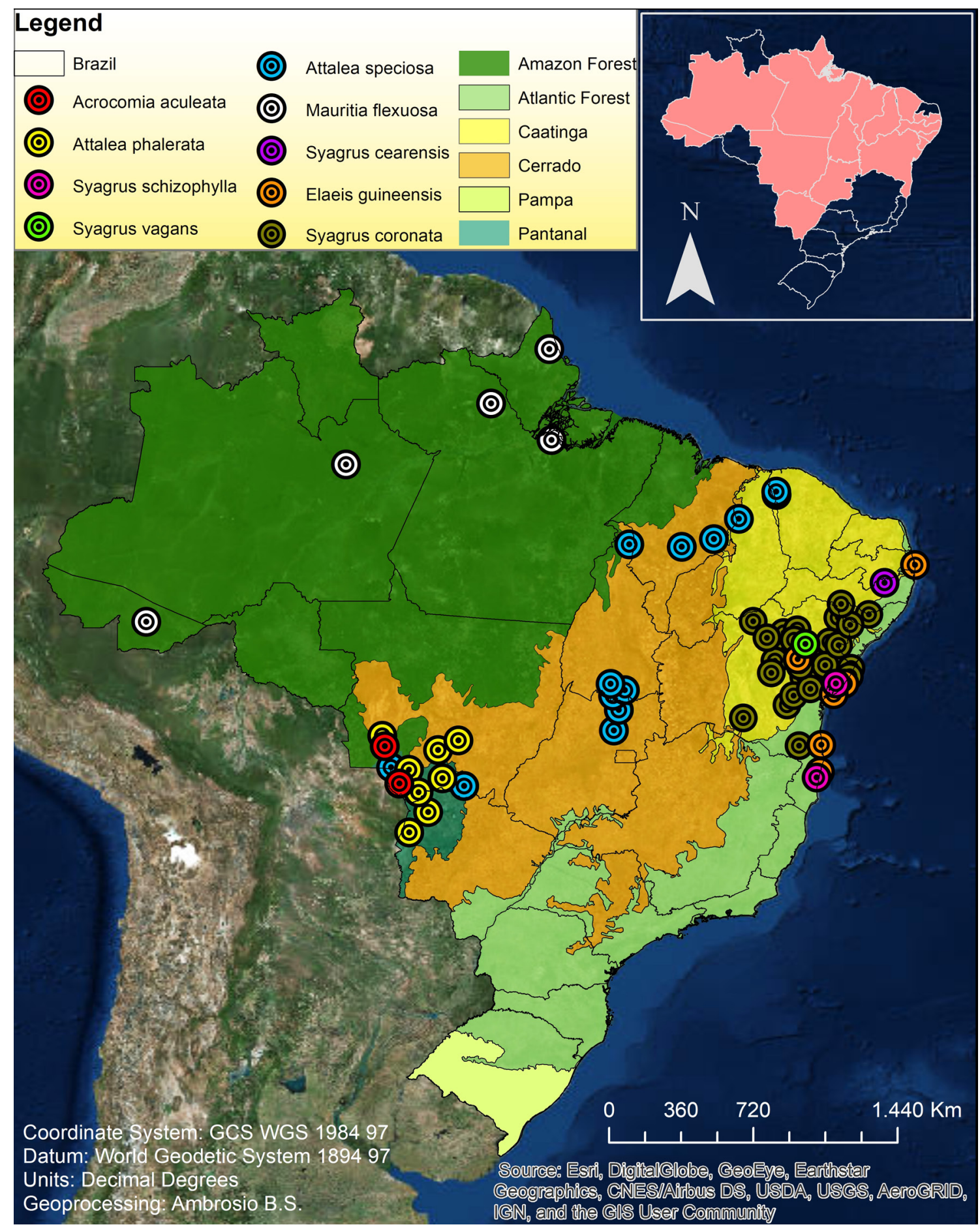

Figure 2 - Records of species of palm phorophytes of Vanilla palmarum (Salzm. ex Lindl.) Lindl. in Brazil. 
the conservation status of $V$. palmarum has yet to be evaluated in Brazil (Flora do Brasil 2020), but according to the present study the species occurs in several phytogeographical domains and municipalities. Although the current geographical distribution of $V$. palmarum is broad, it is discontinuous and closely related to the joint distribution of its phorophytes in Brazil, which are concentrated in the North, Northestern and Central-West regions.

Therefore, it is expected that deforestation, habitat fragmentation and overexploitation of the natural resources associated with palm trees (e.g., Mauritia flexuosa) negatively influence the population size of the palm trees and V. palmarum (Hilário \& Toledo 2016; Benchimol et al. 2017; Vieira et al. 2016).

Arecaceae is an important plant group in tropical forests, contributing to forest structure and composition, to the nesting of psittacines and to the feeding of mammals and birds (PetiniBenelli et al. 2009; see Hilário \& Toledo 2016). The preservation of S. schizophylla, M. flexuosa and the other seven palm species would also conserve V. palmarum, as well as other orchids and epiphytes that use them as phorophytes. Inversely, since Orchidaceae is a flagship plant group (Rech et al. 2011; Cetzal-Ix et al. 2014), V. palmarum may be used to indirectly ensure the protection of palm species and ecological interactions, including plant-animal relationships.

FFVAB thanks Fundação de Amparo à Pesquisa do Estado da Bahia (FAPESB) for financial suport to the project "Estudos florísticos, taxonômicos e ecológicos em Orchidaceae em remanescentes florestais e de restinga na região metropolitana de Salvador, Bahia, Brasil" (DCR0028/2015). FFVAB and NR thank Conselho Nacional de Desenvolvimento Científico e Tecnológico (CNPq) for the fellowship grants (313237/2015-8 and 305139/2016-9, respectively). We are grateful to Erik Wild for revising the English language.

\section{References}

Barthlott W, Biedinger N, Braun G, Feig F, Kier G \& Mutke J (1999) Terminological and methodological aspects of the mapping and analysis of global biodiversity. Acta Botanica Fennica 162: 103-110.

Bastos CA \& Van den Berg C (2012) A família Orchidaceae no município de Morro do Chapéu, Bahia, Brasil. Rodriguésia 63: 883-927.

Benchimol M, Talora DC, Mariano Neto E, Oliveira TLS,
Leal A, Mielke MS \& Faria D (2017) The influence of landscape-scale deforestation on Arecaceae diversity in the Atlantic Forest. Forest Ecology and Management 384: 314-322.

BFG - The Brazil Flora Group (2015) Growing knowledge: an overview of seed plant diversity in Brazil. Rodriguésia 66: 1085-1113.

Castro RA, Fabricante JR \& Siqueira Filho JA (2016) Importância da palmeira Syagrus coronata (Mart.) Beec. para a conservação da riqueza e diversidade de espécies epífitas vasculares na Caatinga. Revista Árvore 40: 1-12.

Centro de Referência de Informação Ambiental - CRIA (2017) Base de dados. Available at <http://splink. cria.org.br/>. Access on 3 January 2017.

Cetzal-Ix W, Alvarez-Mora R, Basu SK, Cosme-Pérez J \& Noguera-Savelli E (2014) Orchid fruit diversity at Puebla Mexico: a new insight into the biodiversity of a fragmented ecosystem with need for conservation and potential for horticultural exploitations in future. In: Nandwani D (ed.) Sustainable Development and Biodiversity 2. Springer International Publishing Switzerland 207-220.

Flora do Brasil (2020, em construção) Instituto de Pesquisas Jardim Botânico do Rio de Janeiro. Available at $<$ http://floradobrasil.jbrj.gov.br/reflora/ floradobrasil/FB12357>. Access on 23 May 2019.

Fotosíntesis (2012) Proyecto Oleoducto Bicentenario. Guía ilustrada de las plantas epífitas del tramo Araguaney-Banadía. Oleoducto Bicentenario de Colombia, Bogotá. 116p.

Freitas RCA, Santos MLG \& Matias LQ (2011) Checklist das monocotiledôneas do Ceará, Brasil. Revista Caatinga 24: 75-84.

Freitas L, Salino A, Menini Neto L, Almeida TE, Mortara SR, Stehmann JR, Amorim AM, Guimarães EF, Coelho MN, Zanin A \& Forzza RC (2016) A comprehensive checklist of vascular epiphytes of the Atlantic Forest reveals outstanding endemic rates. Phytokeys 58: 65-79.

Hilário RR \& Toledo JJ (2016) Effects of climate and forest structure on palms, bromeliads and bamboos in Atlantic Forest fragments of Northeastern Brazil. Brazilian Journal of Biology 76: 834-844.

Hoehne FC (1949) Iconografia das Orchidaceas do Brasil. Secretaria da Agricultura, São Paulo. 601p.

Householder E, Janovec J, Mozambite AB, Maceda JH, Wells J \& Valega R (2010) Diversity, natural history, and conservation of Vanilla (Orchidaceae) in Amazonian wetlands of Madre de Dios, Peru. Journal of the Botanical Research Institute of Texas 4: 227-243.

Huda MK \& Wilcock CC (2011) Colonisation and diversity of epiphytic orchids on trees in disturbed and undisturbed forests in the Asian tropics. Garden's Bulletin Singapore 63: 341-356. 
Lindley J (1840) The genera and species of Orchidaceous Plants. Ridgways, Piccadilly, London. 554p.

Lorenzi H, Noblick LR, Kahn F \& Ferreira E (2010) Flora brasileira - Arecaceae (palmeiras). Instituto Plantarum de Estudos da Flora, Nova Odessa. $368 \mathrm{p}$.

Miranda AF \& Guarim Neto G (2012) Angiospermas epífitas do acuri (Attalea phalerata (Mart. ex Spreng.) Burret) na fazenda Pareia - Mato Grosso - Brasil. Boletim do Grupo de Pesquisa da Flora, Vegetação e Etnobotânica 4: 11-21.

Koch AK, Santos JUM \& Ilkiu-Borges AL (2014) Sinopse das Orchidaceae holoepífitas e hemiepífitas da Floresta Nacional de Caxiuanã, PA, Brasil. Hoehnea 41: 129-148.

Pansarin ER, Aguiar JMRBV \& Ferreira AWC (2012) A new species of Vanilla (Orchidaceae: Vanilloideae) from São Paulo, Brazil. Brittonia 64: 157-161.

Petini-Benelli A, Silva MA \& Macedo M (2009) O uso de Cyrtopodium saintlegerianum Rchb.f. (Orchidaceae) para a confecção de viola-do-cocho em Poconé, Pantanal de Mato Grosso, Brasil. Orquidário 23: 59-65.

Thiers B (2017) Index herbariorum: a global directory of public herbaria and associated staff. New York Botanical Gardens virtual herbarium. Available at $<$ http://sweetgum.nybg.org/ih/>. Access on 9 January 2017.
Trapnell DW \& Hamrick JL (2006) Variety of phorophyte species colonized by the neotropical epiphyte, Laelia rubescens (Orchidaceae). Selbyana 27: 60-64.

Rech AR, Rosa YBCJ \& Rosa-Junior EJ (2011) Levantamento e características ecológicas de Orchidaceae da mata ciliar do Rio Dourados, Dourados-MS. Revista Árvore 35: 717-724.

Rolfe RA (1896) A revision of the genus Vanilla. Botanical Journal of the Linnean Society 32: 439-478.

Soto Arenas MA \& Cribb PJ (2010) A new infrageneric classification and synopsis of the genus Vanilla Plum. ex Mill. (Orchidaceae, Vanillinae). Lankesteriana 9: 355-398.

Vieira TL, Barros F \& Roque N (2014) Orchidaceae no Município de Jacobina, Estado da Bahia, Brasil. Hoehnea 41: 469-482.

Vieira IR, Oliveira JS, Santos KPP, Silva GO, Vieira FJ \& Barros RFM (2016) A contingent valuation study of buriti (Mauritia flexuosa L.f.) in the main region of production in Brazil: is environmental conservation a collective responsibility? Acta Botanica Brasilica 30: 532-539.

Wagner K, Mendieta-Leiva G \& Zotz G (2015) Host specificity in vascular epiphytes: a review of methodology, empirical evidence and potential mechanisms AoB PLANTS 7: plu092. 